\title{
TWO NEW SPECIES OF Galeopsomyia (HYMENOPTERA, EULOPHIDAE) FROM BRAZIL
}

\author{
Nelson Wanderley Perioto', Valmir Antonio Costa ${ }^{2}$, Rogéria Inês Rosa Lara ${ }^{1}$
}

${ }^{1}$ Laboratório de Bioecologia e Taxonomia de Parasitóides e Predadores, APTA Ribeirão Preto. Rua Peru, 1472-A, CEP 14075-310, Ribeirão Preto, SP, Brazil, telefax: +55-16-3626-1609. E-mail: nperioto@apta.sp.gov.br and nperioto2@gmail.com.

${ }^{2}$ Instituto Biológico, APTA. Rodovia Heitor Penteado, km 3. CP. 70, CEP 13001-970, Campinas, SP, Brazil, telefax: +55-19-3252-2942. E-mail: valmir@biologico.sp.gov.br.

\begin{abstract}
This paper presents two new species of Galeopsomyia (Hymenoptera, Eulophidae) from Brazil. The first, Galeopsomyia macaxeira sp. n. was obtained from leaf galls on cassava (Manihot esculenta, Euphorbiaceae) and the second, Galeopsomyia glypta sp. n., was obtained from cocoons of Glyptapanteles sp. (Hymenoptera, Braconidae) parasitizing Thyrinteina arnobia (Stoll, 1782) (Lepidoptera, Geometridae).
\end{abstract}

Key words: eucalyptus, Jatrophobia brasiliensis, Manihot esculenta, Tetrastichinae, Thyrinteina arnobia

\section{DUAS NOVAS ESPÉCIES DE Galeopsomyia (HYMENOPTERA, EULOPHIDAE) DO BRASIL}

\section{RESUMO}

Este estudo apresenta duas novas espécies de Galeopsomyia (Hymenoptera, Eulophidae) do Brasil. A primeira, Galeopsomyia macaxeira sp. n. foi obtida de galhas foliares de mandioca (Manihot esculenta, Euphorbiaceae) e a segunda, Galeopsomyia glypta sp. n., foi obtida de casulos de Glyptapanteles sp. (Hymenoptera, Braconidae) que parasitava Thyrinteina arnobia (Stoll, 1782) (Lepidoptera, Geometridae).

Palavras-chave: eucalipto, Jatrophobia brasiliensis, Manihot esculenta, Tetrastichinae, Thyrinteina arnobia

\section{INTRODUCTION}

The genus Galeopsomyia (Hymenoptera, Eulophidae) comprises 17 species distributed in the New World, 12 of which have Neotropical distribution and five of them were recorded from Brazil (Noyes, 2005). Except $G$. fausta LaSalle, 1997, a parasitoid of the citrus leafminer Phyllocnistis citrella Stainton (Lepidoptera, Gracillariidae) (LaSalle \& Peña, 1997), all known species of Galeopsomyia attack galls, mostly as Cynipidae and Cecidomyiidae parasitoids, but occasionally as inquilines (LaSalle, 1994).

The leaf galls on cassava (Manihot esculenta, Euphorbiaceae) is caused by Jatrophobia brasiliensis (Rubsaamen, 1907) (Diptera, Cecidomyiidae) and have little economic impact but, at severe attack, can deform the leaves and prevent the normal development of young plants. 
Thyrinteina arnobia (Stoll, 1782) (Lepidoptera, Geometridae) is the most harmful defoliator of eucalyptus in Brazil; some larvae were found parasitized by an undetermined species of Glyptapanteles (Hymenoptera, Braconidae) in Anhembi, São Paulo State, Brazil.

\section{MATERIAL AND METHODS}

Specimens of Galeopsomyia macaxeira sp. $\mathrm{n}$. were reared by Neliton Marques da Silva from leaf galls on cassava in Manaus, Amazonas State, Brazil, and the specimens of Galeopsomyia glypta sp. $\mathrm{n}$. were reared by João Ângelo Cerignoni from cocoons of Glyptapanteles sp., which were parasitizing $T$. arnobia on eucalyptus leaves in Anhembi, São Paulo State, Brazil. Observations for descriptions were made using a Leica MZ 9.5 stereomicroscope and fluorescent light source. Images of scanning electron micrographs were made with a Jeol SEM of the "Departamento de Biologia Celular e Molecular e Bioagentes Patogênicos", from the "Faculdade de Medicina de Ribeirão Preto/Universidade de São Paulo". The images were captured on a Neopan 100 film and digitized from the negative using a scanner. The figures were prepared using Adobe(C) Photoshop. Morphological terminology follows Gibson (1997) except for basigastral carina - a strong transverse carina along the anterior margin of the first gastral tergite - and basigastral costula - any longitudinal carina extending posteriorly from the basigastral carina (see LaSalle \& Peña, 1997). Sculpturing terminology follows Harris (1979). Abbreviations are as follows: Fn, flagellomeres $(n=$ number of the flagellomere); Mt $n$, metasomal tergites ( $n=$ number of the metasomal tergite); OOL = ocello-ocular distance; POL = post-ocellar distance.

\section{List of repositories}

MZSP - Museu de Zoologia da Universidade de São Paulo (São Paulo, Brazil). C. R. F. Brandão, curator;

UFES - Universidade Federal do Espírito Santo (Vitória, Brazil). C. O. Azevedo, curator.

Diagnosis: sculpture of the bottom of the triangular fovea below eye not visible; propodeum with median carina bifurcated anteriorly, without other carinae between the median and paraspiracular carinae; petiole indistinct; basigastral costulae present and hardly visible; $\mathrm{Mt}_{l}$ and $\mathrm{Mt}_{4}$ the longest tergites.

Holotype female: length $1.6 \mathrm{~mm}$. Head and mesosoma black with violet and blue-greenish metallic shine except by brown coloration on mandibles, fore (with soft blue-greenish metallic shine) and median coxa, trochanter and femur, which is pale yellow apically; light brown coloration on pedicel, flagellum and tegula; pale yellow coloration on scape, tibiae and tarsus; dark red coloration on eye and ocelli. Gaster dark brown with soft blue-greenish metallic shine. Wings hyaline, setae and veins light brown. Body with white setae.

Head: (Fig. 1) $1.3 \mathrm{x}$ wider than high; POL/OOL 2.3; eye $1.4 \mathrm{x}$ the length of malar space; malar sulcus straight with a small triangular fovea below eye (Fig. 2) (length ca. $0.3 \times$ malar sulcus); gena with shallow sculpturation around fovea, giving a shine aspect; occiput, supraclypeal area and upper and lower face imbricate. Scrobal depression without distinct sulci and with longitudinal median ridge; anterior tentorial pit distinct; clypeus bilobed.

Antenna (Fig. 3): scape $4.5 \mathrm{x}$, pedicel $1.8 \mathrm{x}, \mathrm{F}_{1} 1.6 \mathrm{x}, \mathrm{F}_{2} 1.8 \mathrm{x}, \mathrm{F}_{3} 1.6 \mathrm{x}$ and clava ( 3 segmented) $3.2 \times$ longer than wide, 3 anelli. 
Galeopsomyia macaxeira Perioto, Costa \& Lara sp. n. (Figs. 1-8)
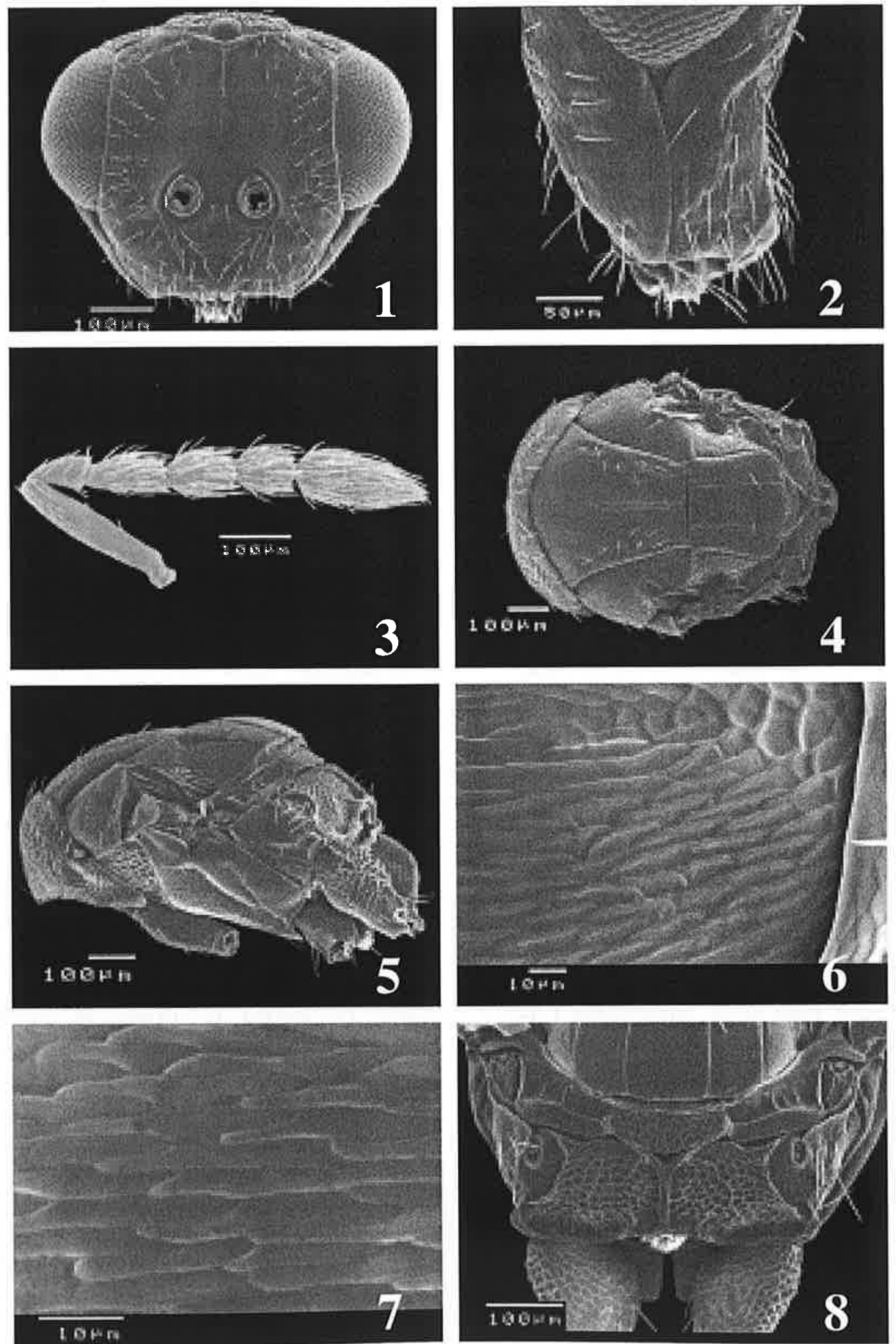

FIGURES 1-8. Galeopsomyia macaxeira sp. nov. female. 1. Head, frontal view; 2. Head, lateral view; 3. antenna; 4. Mesosoma, dorsal view; 5. Mesosoma, lateral view; 6. Mesoscutum, detail of sculpturing; 7. Scutellum, detail of sculpturing; 8. Propodeum. 
Mesosoma (Figs. 4, 5): 1.4 x longer than wide in dorsal view. Mesoscutum imbricate (Fig. 6) dorsally with notauli complete, deep; median sulcus vaguely indicated posteriorly and indistinct anteriorly; 7-9 adnotaular setae irregularly distributed. Scutellum imbricate as in Fig. 7, with 3 pairs of setae, the posterior being the longest; sublateral and submedian lines complete, broad and deep, median sulcus vaguely indicated on anterior portion. Dorsellum reticulated. Propodeum (Fig. 8) reticulated, with median carina bifurcated anteriorly, without other carinae between the median and paraspiracular carinae, posterior margin sharply margined. Petiole inconspicuous.

Fore wing: $2.2 \times$ longer than wide; submarginal vein $1.2 \times$ length of marginal vein; marginal vein $2.9 \times$ length of stigmal vein and post-marginal vein absent; submarginal vein with 4 setae on dorsal surface; speculum and basal cell present, delimited by cubital setal line, basal setal line indicated by 4 setae.

Metasoma: $3.3 \times$ longer than high in lateral view and $3.6 \times$ longer than wide in dorsal view, reticulate, $\mathrm{Mt}_{l}$ and $\mathrm{Mt}_{4}$ in dorsal and lateral view are the longest. $\mathrm{Mt}_{l}$ with a small and hardly visible basigastral costulae.

Variability: body length $1.6-2.3 \mathrm{~mm}$. POL/OOL 1.5-2.3; eye high 1.4-1.9 x malar space; scape 3.8-4.6 $\mathrm{x}$, pedicel 1.6-1.8 x, $\mathrm{F}_{I}$ 1.3-1.7 $\mathrm{x}, \mathrm{F}_{2}$ 1.5-1.8 $\mathrm{x}, \mathrm{F}_{3}$ 1.4-1.7 $\mathrm{x}$ and clava 2.9-3.7 x longer than wide. Mesosoma 1.3$1.5 \times$ longer than wide in dorsal view; mesoscutum with 7-10 adnotaular setae irregularly distributed. Fore wing 2.0-2.5 x longer than wide, submarginal vein $0.9-1.2 \mathrm{x}$ length of marginal vein, marginal vein 2.9$4.1 \mathrm{x}$ length of stigmal vein; submarginal vein with 4-5 setae on dorsal surface. Metasoma 2.7-3.6 $x$ longer than wide in dorsal view and 2.7-3.4 $\mathrm{x}$ longer than high in lateral view.

Male allotype: length $1.3 \mathrm{~mm}$. Similar to females except for: POL/OOL
1.6; eye $1.8 \times$ length of malar space. Antenna with 4 funicular segments. Funicular segments with basal whorls of long setae. Scape $2.7 \mathrm{x}$, pedicel $2.0 \mathrm{x}, \mathrm{F}_{1} 1.0$ $\mathrm{x} ; \mathrm{F}_{2} 2.5 \mathrm{x}, \mathrm{F}_{3} 1.7 \mathrm{x}, \mathrm{F}_{4} 1.7 \mathrm{x}$ and clava (3 segmented) $3.7 \times$ longer than wide. Scape with medial dark brown ventral plaque, ca. $0.5 \times$ length of scape. Mesosoma $1.6 \mathrm{x}$ longer than wide. Fore wing $2.1 \times$ longer than wide; submarginal vein $0.9 \mathrm{x}$ length of marginal vein; marginal vein $3.3 \times$ length of stigmal vein, basal setal line indicated by 3 setae. Metasoma $1.8 \times$ longer than wide in dorsal view and $2.3 \times$ longer than high in lateral view.

Male variation: length $1.1-1.3 \mathrm{~mm}$; head 1.2-1.5 x higher than wide; POL/OOL 1.5-1.9; eye height 1.5-2.2 malar space; scape 1.9-2.8 x, pedicel 1.4-2.0 x, $\mathrm{F}_{l}$ 0.9-1.0 $\mathrm{x}, \mathrm{F}_{2}$ 1.5-2.3 x, $\mathrm{F}_{3} 1.3-2.3 \mathrm{x}, \mathrm{F}_{4} 1.7-2.5 \mathrm{x}$ and clava 3.7-5.3 $x$ longer than wide. Mesosoma in dorsal view 1.4-1.6 $\mathrm{x}$ longer than wide. Fore wing 2.1-2.3 $x$ longer than wide; submarginal vein $0.9-1.1 \times$ length of marginal vein; marginal vein 2.5-3.6 $\mathrm{x}$ length of stigmal vein. Metasoma 1.8-3.0 x longer than wide and 2.3-3.2 $x$ longer than high.

Distribution: Manaus, Amazonas
State, Brazil.
Remarks: G. macaxeira may be distinguished from other species of the genus, with exception of $G$. fausta, by the presence of basigastral costulae on $\mathrm{Mt}_{/}$. From G. fausta it differs in lacking a distinctly visible petiole and basigastral carinae, by having basigastral costulae hardly visible, $\mathrm{Mt}_{1}$ and $\mathrm{Mt}_{4}$ the longest segment and by the fovea bellow eye without visible sculpturation.

Biology: G. macaxeira was reared from leaf galls on cassava and is probably associated to $J$. brasiliensis, the gall maker.

Etymology: the specific epithet refers to one of the popular Brazilian names of cassava. 
Galeopsomyia glypta Perioto, Costa \& Lara sp. n. (Figs. 9-16)
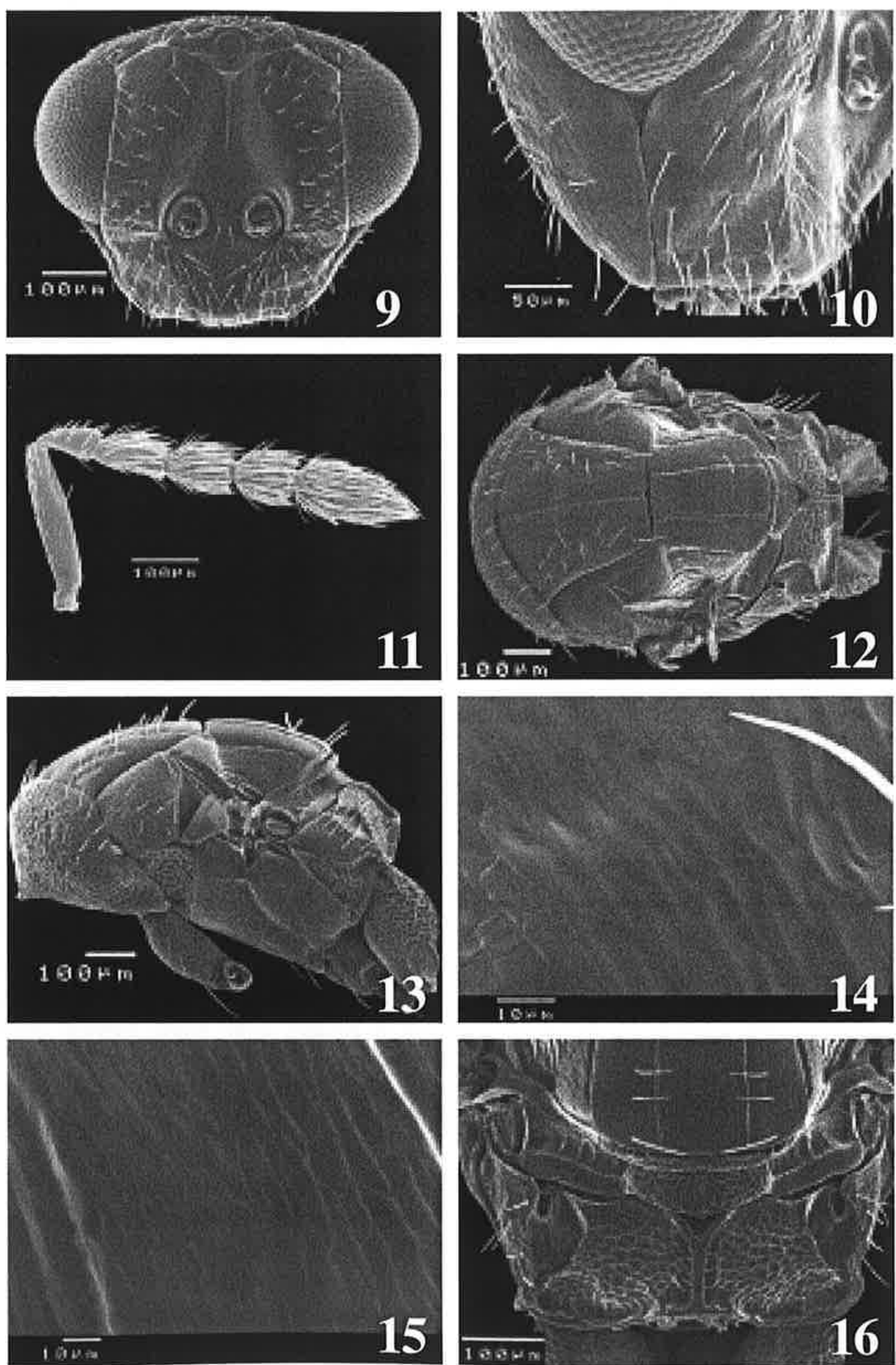

FIGURES 9-16. Galeopsomyia glypta sp. nov. female. 9. Head, frontal view; 10. Head, lateral view; 11. antenna; 12 . Mesosoma, dorsal view; 13 . Mesosoma, lateral view; 14. Mesoscutum, detail of sculpturing; 15. Scutellum, detail of sculpturing; 16. Propodeum. 
Material examined: 12 females, 14 males. HOLOTYPE female: BRASIL, Amazonas, Manaus, 17.VI.2004, N.M. da Silva, col., ex. galha foliar em Manihot sculenta. Deposited in MZSP. ALLOTYPE male: same label as holotype. Deposited in MZSP. PARATYPES: MZSP ( 5 females, 6 males) and UFES ( 6 females, 7 males), same label as holotype.

Diagnosis: Metasoma collapsible, with shallow reticulate sculpturation.

Holotype female: length $2.0 \mathrm{~mm}$. Head, mesosoma, metasoma, metacoxa and gaster black with green metallic shine; fore and median coxa, femur (pale yellow apically) dark brown coloration; mandibles brown; light brown antenna and tegula; tibiae and tarsus pale yellow coloration; eye and ocelli dark red (the ocelli became darker by dehydration). Wings hyaline, setae and veins pale yellow. Body with white setae.

Head: (Fig. 9) $1.4 \mathrm{x}$ higher than wide; POL/OOL 1.9; eye $1.6 \mathrm{x}$ the length of malar space; malar sulcus straight, malar space with a small triangular fovea below eye (length ca. $0.3 \times$ malar sulcus) (Fig. 10); gena and occiput imbricate, supraclypeal area imbricate, upper face punctate imbricate with sparsely punctuation. Scrobal depression without distinct sulci, but with a longitudinal median ridge; clypeus bilobed.

Antenna (Fig.11): scape $5.0 \mathrm{x}$, pedicel $2.3 \mathrm{x}, \mathrm{F}_{1} 1.5 \mathrm{x}, \mathrm{F}_{2} 1.5 \mathrm{x}, \mathrm{F}_{3} 1.3 \mathrm{x}$ and clava ( 3 segmented) $2.5 \times$ longer than wide, 3 anelli.

Mesosoma: $1.4 \times$ longer than wide (Fig. 12, 13) in dorsal view. Mesoscutum dorsally imbricate (Fig. 14) with notauli complete, deep; median sulcus complete; 1113 adnotaular setae irregularly distributed; scutellum imbricate as in Fig. 15, with three pairs of setae (the posterior being the longest), sublateral and submedian lines complete, broad and deep; median sulcus vaguely indicated on anterior portion. Dorsellum reticulated. Propodeum (Fig. 16) reticulated with median carina bifurcated anteriorly, without other carinae between the median and paraspiracular carinae, posterior margin sharply margined. Petiole inconspicuous.

Fore wing: $2.3 \times$ longer than wide; submarginal vein $0.9 \times$ length of marginal vein; marginal vein $4.4 \mathrm{x}$ length of stigmal vein and post-marginal vein absent; submarginal vein with four setae on dorsal surface; speculum and basal cell present, not delimited by cubital setal line, basal setal line indicated by three setae.

Metasoma: Reticulate and collapsible in air dried specimens, $\mathrm{Mt}_{l}$ in dorsal and lateral view is the longest and slightly reticulate.

Variability: body length $1.8-2.0 \mathrm{~mm}$; POL/OOL 1.7-1.9; eye high 1.5-1.6 x malar space; scape 4.3-5.0 x, pedicel 2.0-2.3 x, $\mathrm{F}_{I}$ 1.4-1.5 x, $\mathrm{F}_{2}$ 1.4-1.5 x, $\mathrm{F}_{3} 1.3-1.4 \mathrm{x}$ and clava 2.5-2.7 x longer than wide. Mesosoma 1.3$1.4 \mathrm{x}$ longer than wide in dorsal view; $10-13$ adnotaular setae irregularly distributed. Fore wing 2.0-2.3 $\mathrm{x}$ longer than wide; submarginal vein $0.9-1.0 \times$ length of marginal vein; marginal vein 4.4-4.8 $\mathrm{x}$ length of stigmal vein.

Male allotype: length $1.3 \mathrm{~mm}$. Similar to females except for: POL/OOL 2.0 ; eye $1.8 \times$ length of malar space. Funicular segments with whorls of long setae; setae of $\mathrm{F} 1$ reaching base of clava; scape $3.0 \mathrm{x}$, pedicel $1.3 \mathrm{x}, \mathrm{F}_{1} 1.1 \mathrm{x}, \mathrm{F}_{2} 1.9 \mathrm{x}$, $\mathrm{F}_{3} 2.5 \mathrm{x}, \mathrm{F}_{4} 2.5 \mathrm{x}$ and clava ( 3 segmented) $5.8 \times$ longer than wide, ventral plaque of scape ca. $0.4 \mathrm{x}$ length of scape, light brown with basal portion dark brown. Mesosoma $1.1 \times$ longer than wide, 4-5 adnotaular setae. Fore wing $2.1 \mathrm{x}$ longer than wide, submarginal vein $0.9 \mathrm{x}$ length of marginal vein, marginal vein $4.9 \times$ length of stigmal vein, submarginal vein with 4 setae.

Male variation: length $1.3-1.6 \mathrm{~mm}$. Head 1.1-1.4 $x$ higher than wide; POL/OOL 1.9-2.0; eye height 1.5-1.8 malar space; scape 2.7-3.0 x, pedicel 1.3-1.7 x, $\mathrm{F}_{1} 1.1-1.3$ $\mathrm{x}, \mathrm{F}_{2} 1.9 \mathrm{x}, \mathrm{F}_{3} 2.0-2.5 \mathrm{x}, \mathrm{F}_{4} 2.1-2.5 \mathrm{x}$ and 
clava 4.1-5.8 $\times$ longer than wide, ventral plaque $0.4-0.7$ length of scape. Mesosoma in dorsal view 1.1-1.4 $\mathrm{x}$ longer than wide. Fore wing $2.1 \times$ longer than wide, submarginal vein 0.9-1.1 $x$ length of marginal vein, marginal vein $4.3-4.9 \times$ length of stigmal vein.

State, Brazil.

Distribution: Anhembi, São Paulo

Remarks: Unlike the other species of this genus, G. glypta has slight reticulate sculpturation on metasoma; $\mathrm{Mt}_{l}$, in dorsal and lateral view, is the longest tergite. Unlike G. fausta and G. macaxeira, $G$. glypta has no basigastral carinae and costulae. This is the first species of the genus whose metasoma collapses in air dried specimens.

Biology: G. glypta was obtained from cocoons of Glyptapanteles sp., which were parasitizing $T$. arnobia larvae on eucalyptus leaves.

Etymology: the specific epithet refers both to its surface sculpturing and to its host, Glyptapanteles sp.

Material examined: 4 females, 4 males. HOLOTYPE: BRASIL, São Paulo, Anhembi, 1.VI.2003, J.A. Cerignoni, col., ex casulos de Microgastrinae em Thyrinteina arnobia em eucalipto. Deposited in MZSP. PARATYPES: MZSP (1 females, 1 males) and UFES (2 females, 2 males), same label as holotype.

\section{ACKNOWLEDGMENTS}

The authors thank Dr. Angélica Maria Penteado-Dias ("Universidade Federal de São Carlos") for the identification of Glyptapanteles sp.

\section{REFERENCES}

GIBSON, G.A.P. 1977. Morphology and terminology. In: GIBSON, G.A.P., HUBER, J.T. \& WOOLLEY, J.B. (Eds.). Annotated keys to genera of Nearctic Chalcidoidea (Hymenoptera). NRC Research Press, Ottawa, p.16-44.

HARRIS, R.A. 1979. A glossary of surface sculpturing. Occasional Papers in Entomology, 28: 1-31.

LASALLE, J. 1994. North American genera of Tetrastichinae (Hymenoptera: Eulophidae). Journal of Natural History, 28: 109-236.

LASALLE, J. \& PEÑA, J.E. 1997. A new species of Galeopsomyia (Hymenoptera: Eulophidae: Tetrastichinae): a fortuitous parasitoid of the citrus leafminer, Phyllocnistis citrella (Lepidoptera: Gracillariidae). Florida Entomologist, 80(4): 461470.

NOYES, J.S. 2007. Universal Chalcidoidea Database. The Natural History Museum. Available from:

$<\underline{\text { http://www.nhm.ac.uk/research- }}$ curation/projects/chalcidoids/>. Accessed 21 Aug. 2007. 